【土木計画学研究・論文集 No.3 1986年 1月】

\title{
交通量配分におけるQ－V式の設定方法に関する研究 \\ Development of a Speed-Volume Relationship \\ for Use in Traffic Assignment
}

松井寛 ${ }^{*}$. 藤田素弘 $* *$

By Hiroshi MATSUI and Motohiro FUJITA

\begin{abstract}
Traffic assignment is the process of allocating a set of OD trips to various routes of the transportation network. Usually traffic assignment is made for an entire day. The most cormon assignment techniques use $\mathrm{Q}-\mathrm{V}$ curves, which show the speed-volume relationships, in order to take into account the effects of traffic congestion. However, these $Q-V$ curves have been determined ideally or empirically and have not been based on field data.

In this paper we present a new method which can make up a $Q-V$ curve applicable to traffic assignment for an entire day by using the $\mathrm{Q}-\mathrm{V}$ curve observed for an hour and the hourly variation pattern of traffic.
\end{abstract}

1 はじめに

実際的な交通量配分を行う手段として、容量制的 のある交通量配分手法が現在広く用いられているが、 この容量制約は、具体的には各道路区間に $Q-V$ 式 (交通量一速度曲線) を導入するてとによって行わ れるのが一般的である。交通量配分はまた通常全日 交通量を対象とされるので、Q-V式もまた日交通 量と日平均旅行速度の関係を表すものと理解されて いるが、この両者の関係式は、短時間、たとえば 1 時間単位で得られる $\mathrm{Q}-\mathrm{V}$ 式と異なり、実测データ に基ついて決めるてとが困難なため、現在用いられ ている日単位のQ-V式は、势い覾念的、経鈳的に 与えざるを得ない。 このように、交通量配分に用いるQ-V式は、配 *正会員 工博 名古屋工業大学教授 工学部社会 開発工学科 ( $\bar{T} 466$ 名古屋市昭和区御器所町) **学生会員 名古屋工業大学院生 工学部社会開 発工学科 ( $\bar{T} 466$ 名古屋市昭和区御器所町)
分理論自体の最近の著しい発展に比べて、その重要 性にもかかわらず従来理論的な検討が十分になされ ていないのが現状である。最近は交通量配分の結果 が単に道路計画だけではなく、沿道環境の事前評価 の基礎データとしても使用したいという行政側の要 請も強く、したがってより信頼性の高い交通量配分 計算を行うことが要求されてきている。そてで本論 文では、交通量配分に用いる 1 日単位の $Q-V$ 式を 実测データに基ついた時間単位のQ $\mathrm{Q}-\mathrm{V}$ 式から構築 する新しい方法を提案し、実測デー夕に基づいた $Q$ $-V$ 式を実際に求め、従来経験的に与えられた $Q-$ $\mathrm{V}$ 式と比較するてとによって、本論文で提案した新 しいQ-V式の構造と特賀を明らかにする。

\section{2 従来の研究}

交通量配分手法において、道路混雑による旅行時 間の增加（旅行速度の低下）の影響を具体的に導入 する方法として、各道路区間でとに設定された交通 
量と旅行時間の関係を表す曲線（以下容量関数と呼 ぶ）か、交通量と旅行速度の関係を表す曲線（以下 $\mathrm{Q}-\mathrm{V}$ 式と呼ぶ）を用いることによって表すのが一 般的である。前者の容量関数の代表的なものとして は、反復計算による配分手法として知られている B P R 法 ${ }^{1}$ 、Wayne 法 ${ }^{2}$ 、T R C 法 ${ }^{31}$ などで用いられ たものがあり、一方後者の $Q-V$ 式には、分割配分

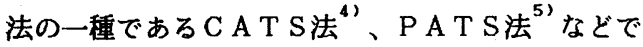
用いられたものが知られている。しかしながら、て れらはT R C 法を除いていずれも観念的あるいは経 験的に与えたもので、実際の交通現象から導き出さ れたものではない。たた T R C 法では、実測データ に基ついて、車種別、規制速度別、信号交差点密度 別に設定した20種の容量関数を用いている点に特徵 がある。しかしながらての容量関数においては交通 量が時間単位にとられており、したがって日単位の 交通量配分問題等には適用できない。一方、Davids on ${ }^{6)}$ は待ち合わせ理論に基ついた容量関数を提案し ているが、ての関数においても交通量が時間単位に とられており、時間交通量の配分問題にしか適用で きない。

欧米においては容量関数を用いるのがどちらかと いえば主流であるのに対し、かが国においては、各 都市圈で実施されたパーソントリップ調查に基づく 需要予测をはじめ、交通量配分には伝統的に $\mathrm{Q}-\mathrm{V}$ 式を用いることが多い。図一1はわが国で用いられ ている $\mathrm{Q}-\mathrm{V}$ 式の代表的な例を示したものである。
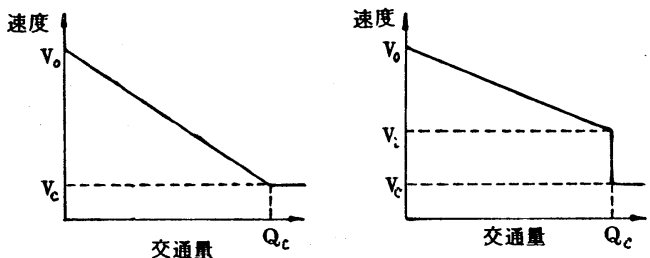

因一 1 交通量配分に用いられるQ-V式

しかしながら、てれらのQ-V式をいずれも日交通 量と日平均旅行速度の関係を㘥念的にグラフ化した に過ぎず、論理性に欠けていると言わざるを得ない。 最近の研究例では北川ら”が実測デー夕に基づく日 単位のQ $\mathrm{Q}-\mathrm{V}$ 式の設定方法について提案を行ってい るが、その論理性においてなお問題点を残している。 一方文献 $(8)$ では実测データに基つく時間単位のQ $-V$ 式から日単位の $Q-V$ 式を求める方法を提案し ているが、実際にQ-V式を求めるに至っていない。
$3 \quad \mathrm{Q}-\mathrm{V}$ 式の理論的導出

前述のと打り交通量配分問題は、通常日交通量を 対象としているため、日単位の交通量を求めるため の $\mathrm{Q}-\mathrm{V}$ 式を以下では日 $\mathrm{Q}-\mathrm{V}$ 式と呼ぶことにし、 乙の日 $Q-V$ 式を求める方法について考える。まず 道路の交通容量の標準的な単位が時間交通量である こと、また時間単位であれば、実测データからの回 漏によって時間単位の $Q-V$ 式を求めるてとが可能 であるので、いま実測データから求められた時简単 位の $\mathrm{Q}-\mathrm{V}$ 式を以下では時間 $q-v$ 式と㭔ぶととに し、乙の時間 $q-v$ 式から日 $\mathrm{Q}-\mathrm{V}$ 式を導出する方 法について考える。

まず前提条件として以下の 2 つの仮定をおく。 仮定 I：各道路区間の時間 $q-v$ 式は各時間帯に共 通である。

仮定 II：各道路区間の交通量の24時間変動パターン は、配分される日交通量とは無関係に一定 である。

仮定Iに関していえば、たとえば昼間と夜間では時 間 $q-v$ 式が多少異なることも予想されるが、交通 量配分に用いる Q-V式は元来マク口なとらえ方で あるので、この差異は無視し得るとしても差し支え ないであろう。また仮定】は 1 時点における仮定で あり、時間変動パターンの経年的な㚆化と否定する ものではない。

さて、ある道路区間の各時間带の交通量を $q_{i}(i$ $=1,2, \cdots, 24)$ 、平均旅行速度をしi、また日交通量 をQ $\mathrm{Q}$ とくと、日平均旅行速度 Vは、時間带別旅行 速度 $U_{i}$ を交通量 $q_{i}$ で加重平均した值として

$$
\mathrm{V}=\frac{\sum_{i=1}^{24}\left(q_{i} \times U_{i}\right)}{\sum_{i=1}^{24} q_{i}}=\frac{\sum_{i=1}^{24}\left(q_{i} \times V_{i}\right)}{\mathrm{Q}}
$$

で与えられる。時間 $q-v$ 式は前述のように実測デ 一タに基ういて与えるてとになるが、従来の研究 では、交通流が自由流のときは、交通流と平均速度 との関係が直線関係で表されることが知られている ので、いま時間 $q-v$ 式として

$$
v_{i}=a-b q_{i} \quad(i=1,2, \cdots, 24)
$$

なる線形式を仮定すると（ $\alpha$, bは未知のパラメ一 タ）、前述の仮定 I より（以下では簡単のため $\sum_{i=1}^{24}$ こと省略して書く)、 


$$
\mathrm{V}=\frac{\Sigma\left\{q_{i} \times\left(a-b q_{i}\right)\right\}}{\mathrm{Q}}=a-b \frac{\Sigma q_{i}^{2}}{\mathrm{Q}}
$$

となる。さらにててで時間係数 $\eta_{i}\left(=q_{i} / Q\right)$ を 用いることにすれば、

$$
\mathrm{V}=a-b \frac{\Sigma\left(\eta_{i} \mathrm{Q}\right)^{2}}{\mathrm{Q}}=a-b\left(\Sigma \eta_{i}^{2}\right) \mathrm{Q}
$$

さらに $\eta_{i}$ の平均を六、分散を $\sigma_{2}^{2}$ とすれば、

$$
\begin{gathered}
\bar{\eta}=\Sigma \eta_{i} / 24=1 / 24 \\
\sigma_{\eta}^{2}=\Sigma \eta_{i}^{2} / 24-\bar{\eta}^{2}= \\
\text { となり、式(6)より } \\
\Sigma \eta_{i}^{2}=24 \sigma_{\eta}^{2}+1 / 24
\end{gathered}
$$$$
\sigma_{\eta}^{2}=\Sigma \eta_{i}^{2} / 24-\bar{\eta}^{2}=\Sigma \eta_{i}^{2} / 24-(1 / 24)^{2}(6)
$$

であるから、これを式(4)に代入すると、結局日Q -V式として

$$
\mathrm{V}=\alpha-\frac{b}{24}\left(24^{2} \sigma_{2}^{2}+1\right) \mathrm{Q}
$$

が得られる。仮定IIより分散 $\sigma_{2}^{2}$ は日交通量 $\mathrm{Q}$ と無 関係に一定值をとるから、式（８)で与えられる日Q -V式は日交通量Qに関して線形となる。

このように日 $\mathrm{Q}-\mathrm{V}$ 式が時間 $q-v$ 式と交通量の 24時間変動の分散 $\sigma_{2}^{2}$ とから理論的に構築できると とが明らかとなった。ここで注目すべき点は、日Q -V式の傾きが交通量の24時間変動の分散によって 修正される構造をもつてとが明示された点であり、 したがって同一の道路区間であっても、時間変動の 分散が変われば異なった日 $\mathrm{Q}-\mathrm{V}$ 式を与えるという てとである。ただ24時間変動パターンが変化しても、 その分散さえ同じであれば、日 $\mathrm{Q}-\mathrm{V}$ 式に変化を与 えないことに注意しなければならない。

$$
\text { 式(8)において } \sigma_{\eta}^{2}=0 \text { とおくと、乙れは、交通 }
$$
量に時間変動が全くない状態であるから、日交通量 は単純に時間交通量の24倍 $(Q=24 q)$ として与えら れるので

$$
\mathrm{V}=a-\frac{b}{24} \mathrm{Q}=a-b q
$$

となり、時間 $q-U$ 式と同形となる。したがって、 時間変動の全くない需要交通量を配分する場合には、 時間 $q-U$ 式を用いて配分した時間交通量を単純に 24倍したものが、日 $\mathrm{Q}-\mathrm{V}$ 式を用いて配分した結果 と一致することが明らかである。
同様に時間 $q-v$ 式を高次の多項式

$$
v_{i}=\alpha-b_{1} q_{i}-b_{2} q_{i}^{2} \cdots-b_{n} q_{i}^{n}
$$

で与えた場合は、日 Q-V式は同様に

$$
\mathrm{V}=a-\sum_{j=1}^{n} b_{j}\left(\sum_{i} \eta_{i}^{j+1}\right) Q^{j}
$$

となり、仮定した時間 $q-v$ 式と同じ次数の多項式 で表わされることが証明できる。

交通量配分の計算結果から得る情報としては、単 に各道路区間の日交通量と日平均旅行速度だけでは なく、ある特定時間帯、たとえばピーク時間帯にお けるピーク時交通量とピーク時平均旅行速度を知り たいてとも多い。このときは、ピーク時交通量とピ 一ク時平均旅行速度をそれそれれ $q_{p}, v_{p}$, またピ一 ク率を施と扔ば、次式によって $q_{p}, U_{p}$ 求め るととができる。

$$
\begin{aligned}
& q_{p}=\eta_{p} \mathrm{Q} \\
& v_{p}=\alpha-\frac{24 \eta_{p}}{24^{2} \sigma_{\eta}^{2}+1}(\alpha-\mathrm{V})
\end{aligned}
$$

このように、日単位の交通量と旅行速度と特定時間 帯（上式ではピーク時）の交通量と旅行速度との間 には、 1 対 1 の対応関係があることがわかる。

\section{4 分割配分法と日 $Q-V$ 式との関係}

現在最も広く用いられている実用的な配分手法と して分割配分法がある。ての方法は交通量の分割方 法によってさらに分類できるが、”が国で広く用 いられている方法は、まず配分対象となる全交通量 せあらかじめ $\mathrm{N}$ 分割し、最初の 1 部をまず最短経路 に配分し、次に Q-V式を用いて各道路区間の旅行 速度を修正し、再び新しい最短経路を見い出し、そ の経路に次の 1 部の交通量を配分するといった繰返 しによって、全交通量をN回に分けて配分する方法 である。各道路区間の区間交通量は、各回でとに配 分された交通量を単純に累加するととによって求め られる。分割配分法はその計算過程から明らかなよ うに等時間原則配分の近似解法とみなされる。 てではてのような分割配分法と先に導出した日Q－ V式との関係について触れてみよう。

いま分割配分法の計算過程で、ある道路区間の $\mathrm{n}$ 分割段階目までの糸加区間交通量を $Q_{n}$, 乙れに対応 する平均旅行速度を $\mathrm{V}_{n}$,また $\mathrm{n}$ 分割段階目までの時 
間帯別の累加時間交通量を $\mathrm{q}_{\text {in }}(i=1,2, \cdots \cdot 24)$ 、 乙れに対応する平均旅行速度を $\mathrm{v}_{\text {in }}$ とすると、 $\mathrm{V}_{n}$

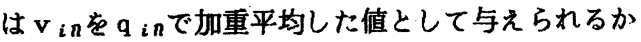
ら、

$$
V_{n}=\frac{\sum_{i}\left(q_{i n} \times v_{i n}\right)}{\sum_{i} q_{i n}}=\frac{\sum_{i}\left(q_{i n} \times v_{i n}\right)}{Q_{n}}
$$

のように表わせる。先と同様に線形の時間 $q-\nu$ 式 を仮定し、また交通量の分割を図一2に示すように

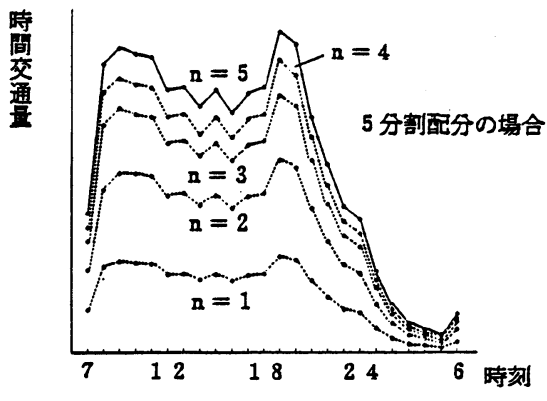

因一2 分割配分法に扔け万交通贯の分割

分割配分の各段階で同形な24時間変動バターンを維 持しながら配分していくものとすれば、時間係数 $\eta$ $\left(=q_{i n} / Q_{n}\right)$ は段階数 $n$ に無関係に一定となる。 よって式(14)は、

$$
\begin{aligned}
\mathrm{V}_{n} & =\frac{\sum\left\{\eta_{i} Q_{n} \times\left(a-b \eta_{i} Q_{n}\right)\right\}}{Q_{n}} \\
& =a-b\left(\sum_{i} \eta_{i}^{2}\right) Q_{n}, \quad(n=1,2, \cdots N)
\end{aligned}
$$

と書き直せる。

上式は式 (4)と同一であり、分割配分法における 途中段階における累加交通量とそれに対応する平均 旅行速度の值は、先に求めた日 $\mathrm{Q}-\mathrm{V}$ 式のグラフ上 に常に位置しているてとがわかる。またての性質は 分割方法とは無関係に成立する。すなわち、分割配 分法とは、各道路区間でとに固有な24時間変動パタ ーンを䊒持しながら、図-2 2 に示すような分割配分 によって平均旅行速度を修正する方法であるという てとができ、分割配分法で用いられる $Q-V$ 式は先 に導出した日Q-V式にうまく対応しているてとが わかる。

5 時間 $q-v$ 式の作成

日 $\mathrm{Q}-\mathrm{V}$ 式の設定にあたっては、前述のように時 間 $q-v$ 式を実測データに基づいて求めておかなけ
ればならない。ところで、道路特性や交通特性のデ 一夕に基ついた統計的分析によって、道路区間の平 匀的な旅行速度を推定しようとするモデルの研究は すでに数例存在する。大蔵ら ${ }^{13)}$ は全国道路交通情势 調查（以下道路交通センサスと呼ぶ）のデータに基 ういて、2 車線および 4 車線の一般道路の平均旅行 速度を推定するための線形重回㷌式を提案している。 岩賴ら“济市内道路において独自の旅行速度調查 を実施し、旅行時間分布の統計的性賀を明らかにす ると共に、道路を信号交差点密度で区分した上で、 平均旅行速度とその生起確率を推定する方法につい て提案を行っている。また北川ら”は、やはり独自 に旅行速度調查を実施し、これを常時観即交通量デ 一タと道路交通センサスのうちの道路状況調査デー 夕を用いて、信号交差点密度と道路種類によってク ラス分けした上で、時間交通量のみを説明変数とす る線形重回帰式を提案している。乙のほかに交通情 報提供、経路誘導等の交通管制に用いるための旅行 時間予測モデルの研究例 ${ }^{151,16), 17 ! ~ も あ る か ゙ 、 乙 ~}$ れらはいずれもオンライン，リアルタイムな予测を めざす動的かっミクロなモデルということができる。

本研究に扔いては、交通量配分に用いる $Q-V$ 式 を求めることが究極の目的であることから、道路条 件と交通条件を示す指標の中から時間交通量を含む 適当な説明指標を選び、回掃分析に基づくマクロな モデルを構築するのが妥当である。用いるデー夕は 沉用性と実用性のあるQ $\mathrm{Q}-\mathrm{V}$ 式を作成するという目 的にてらして、容易に入手できある程度広域的なデ 一タが整えられるという要件から、一般道路につい ては道路交通センサスのうちの一般交通量調査（道 路状況調查、交通量調査、旅行速度調査より成る) の愛知県内分 (昭和55年度) のデータを用いること にした。ただ、高速道路関連のデータについては、 道路交通センサスではサンプル数が不十分なため、 高速道路の交通量と速度のデータについては、阪神 高速道路の車両感知器による自動計測の結果（昭和 59年 5月24日計測）で代用することにした。ただし このときの速度は地点速度の平均値であり、綮密に いえば旅行速度と異なるが、高速道路は一般道路と 異なり交通流の中断要因がないので、近似的に同じ と考えて差し支えないと判断した。データの分析に あたっては、まず旅行速度と時間交通量との相関図 
を作成、検討し、過去の研究(例" ,8) , 13) も参考保 しながら、一般道路においては $15 \mathrm{~km} /$ 時以下、高速 道路においては $50 \mathrm{~km} /$ 時以下の速度を持つサンプル は、涉滞領域にあるものとみなして除外した結果、 最終的に分析に用いたデータ数は一般道路が 524サ ンプル、高速道路が 175サンプルである。四ー3お よび図-4に、データから得られた一般道路と高速 道路における旅行速度と交通量との散布図を示す。

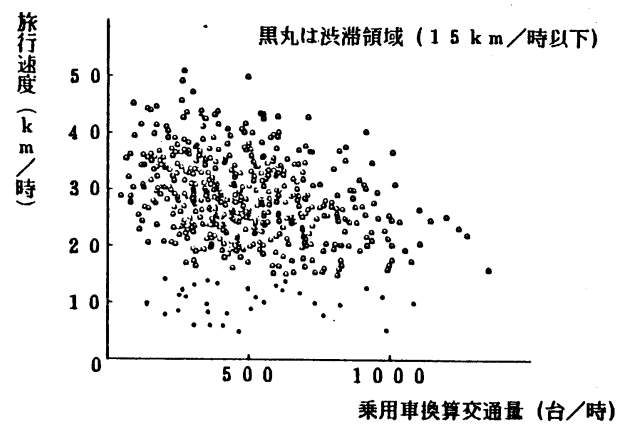

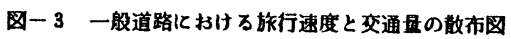

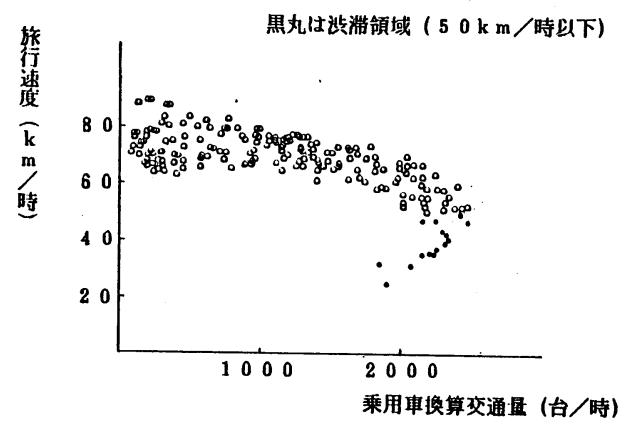

四ー4高速道路におるる旅行速度と交通量の散布四

一般に道路区間上の旅行速度に影響を及ぼす要因 には、交通量をはじめ多くの諸要因が考えられるが、 道路交通センサスの結果から入手可能な範囲で旅行 速度に影響を及ぼすと考光られる要因を摘出すると 表一1に示すとおりである。

交通量配分に用いられてきた従来のQ $-V$ 式の多 くは、道路計画との対応が付け易いように道路構造 命に基うく道路区分に対応して作成されている。本 研究においても沉用性と実用性を重視して、従来の

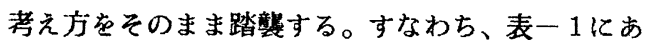
げた要因の中から、道路要因である道路種別と車線 数との組合せによってまずモデルを区分し、残りの

\begin{tabular}{|c|c|c|}
\hline \multicolumn{3}{|c|}{ 族行速度に影旿す万要因 } \\
\hline 区 & 影 知 要 因 & 借考 \\
\hline 沿道要因 & 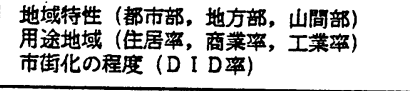 & $\hat{1}$ \\
\hline 道路要因 & 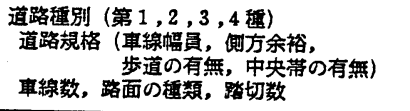 & $\begin{array}{l}\text { 要 } \\
\text { 因 }\end{array}$ \\
\hline 交通通用要因 & 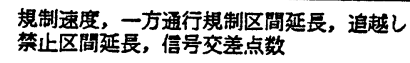 & "ै \\
\hline 交通要因 & $\begin{array}{l}\text { 交通量, 大型車混入率, 二输蕇混入率 } \\
\text { 混程度 }\end{array}$ & 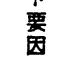 \\
\hline
\end{tabular}

沿道要因、交通運用要因、および交通要因の中から 適当な説明要因を選んでモデル式を作成する方針を とった。ただし本研究では第 1 種道路（都市間高速 道路に相当)については十分なデータの入手ができ なかったので、今回の分析からは除外し、また第 3 種（地方部）と第 4 種（都市部）の道路についても、 事前に椿討した旅行速度と交通量との散布図におい て有意な差を見い出せなかったので、第 3 種と第 4 種を合わせて一般道路としてモデル化することとし、 地域による沿道条件の違いは、説明要因としてモデ ル本体の中に組込をととにした。また車線数につい ては、一般道路は 2 車線道路と多車線道路、都市高 速道路は片側 2 車線道路と片側 $3 \cdot 4$ 車線道路 (一 方通行区間も含む）とに区分するとととした。

表一 2 は今回の分析に用いた説明指標一覧である。 表一2 分析に用いた説明指嫖

\begin{tabular}{|c|c|}
\hline 説 明 指 標 & 単 位 \\
\hline 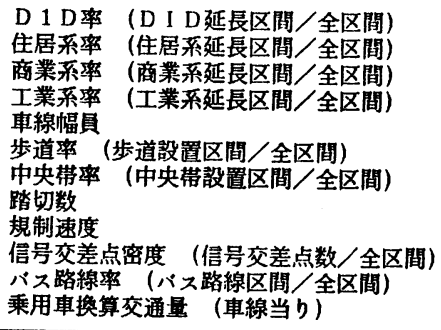 & $\begin{array}{l}{[\%]} \\
{[\%]} \\
{[\%]} \\
{[\%]} \\
{[\mathrm{m}]} \\
{[\%]} \\
{[\%]} \\
{[\% \text { 箅所] }} \\
{[\mathrm{km} / \text { 時] }} \\
{[\text { 䈏所/km] }} \\
{[\%]} \\
{[\text { 台/時/車線] }}\end{array}$ \\
\hline
\end{tabular}

旅行速度と諸説明指標との相関分析の結果は次のと おりである。

(1). 沿道要因として、一般道路に扔いてD I D 率と 商業率が比較的高い負の相関と示した。ただし D I D率と商業率との間の相関係数も 0.6 前後と比較的 高い。

(2). 道路要因としては、元のデータがすでに道路種 
別によって分離されているため、強い相関を示す説 明指標はみあたらなかった。

(3). 交通運用要因として、一般道路では 2 車線、多 車線道路ともに信号交差点密度が比較的高い負の相 関を示した。乙の傾向は従来の研究 ${ }^{7,111,141}$ から も裹付けられている。因一 5 は 2 車線一般道路にお ける旅行速度と信号交差点密度との散布図を示した ものである。このほか一般道路、都市高速道路に共

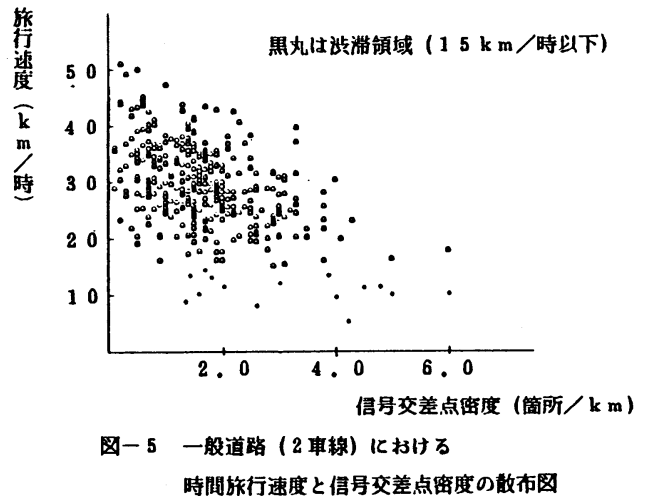

通にみられる比較的相関の高い説明指標として規制 速度があげられる。

(4). 交通要因として、乗用車換算交通量が一般道路、 都市高速道路ともに高い負の相関を示した。とくに 都市高速道路では片側 2 車線道路で相関係数が 0.748 ,片側 $3 \cdot 4$ 車線道路で-0.823 と飛び抜けて 高い値を示している。なお交通量の単位として車線 当り乗用車換算交通量を採用することにより、車種 構成による影響度を間接的に考慮した。

以上の分析結果に基ついて、比較的相関の強い説 明指標をいくつか組合せてモデルを作成した結果、 最終的に表一 3 に示すような重回帰モデル式を得た。
有意性検定の結果は良好であり、おおむね妥当な結 果といえる。ただ一般道路の重回㷌式の重相関係数 が都市高速道路に比べてかなり低い。乙の原因の 1 つとして考えられるのは、一般道路上の旅行速度調 查が 1 回の試験走行に基づくものであり、元のデー 夕自体の信頼性に問題がありそうである。旅行速度 に関する実測データを十分整備するてとが本研究を 進める上での課題と考学られる。また多車線一般道 路でD I D率が説明指標から落ちているが、これは 多車線道路のデータがほとんど都市部に偏在してい たため意味をなさなかったためと思われる。

6 日 Q - V 式の設定例

実測データに基づいて時間 $q-U$ 式が前述のよう に定まると、てれを用いて実際の道路区間の交通量 配分に用いる日 $\mathrm{Q}-\mathrm{V}$ 式が設定できる。道路区間が 設定されると信号交差点密度、規制速度、D I D 率 がそれぞれ定まるので、表一 3 中の重回帰式中の乙 れら 3 説明指標中の項は定数値をとるので、これに 定数項の值を加えたものが、日Q-V式(8)に扔 る $a$ の値となる。一方 $b$ の值は表一 3 の乗用車換算 交通量に䋆る偏回㷌係数である。また $\sigma_{\eta}^{2}$ の值は当 該道路区間の時間変動がわかれば計算できる。困一 6 から図ー9は実際の道路区間のデータを用いて計 算した日Q－V式を示したものである。なお比較の ため、中京都市圈パーソントリップ調查の需要予測 の際に用いられた従来の日 $Q-V$ 式を破線で示した （ただし四中の垂線で示される日交通容量、及び啮 滞時の速度は従来の日 $\mathrm{Q}-\mathrm{V}$ 式の算定方法に従ったり。 両者を比較すると、本論文で提案した日 $\mathrm{Q}-\mathrm{V}$ 式 の方が一般に勾配が緩やかな直線となることがわか

表一 3 時間 $q-v$ 式の回漏分析結果

\begin{tabular}{|c|c|c|c|c|c|c|c|c|c|}
\hline 道路䀒別 & 車線数 & $\begin{array}{c}\text { 定数項 } \\
{[\mathrm{k} \mathrm{m} / \text { 時] }}\end{array}$ & $\begin{array}{c}\text { 信号交差点 } \\
\text { 密 度 } \\
\text { [䉪兹 / k m ] }\end{array}$ & $\begin{array}{c}\text { 規制速度 } \\
\text { [ k m/時] }\end{array}$ & $\begin{array}{c}\text { DI D率 } \\
\text { [\%] }\end{array}$ & $\begin{array}{c}\text { 乗用車換算 } \\
\text { 交通量 } \\
\text { [台/時] }\end{array}$ & $\mathrm{F}$ 值 & 重相䦎 & $\begin{array}{l}\text { サンプ } \\
\text { ル数 }\end{array}$ \\
\hline \multirow{2}{*}{$\begin{array}{c}\text { 都市高速道路 } \\
\text { [第 } 2 \text { 種] }\end{array}$} & $\begin{array}{l}\text { 2車線 } \\
\text { (片側) }\end{array}$ & 56.4 & - & $\begin{array}{r}0.437 \\
\left(7.759^{*}\right) \\
\end{array}$ & - & $\begin{array}{r}-7.675 \times 10^{-3} \\
\left(12.304^{*}\right) \\
\end{array}$ & $116.07^{* * *}$ & 0.869 & 78 \\
\hline & $\begin{array}{l}3 \cdot 4 \text { 車線 } \\
\text { (片側) }\end{array}$ & 81.3 & - & - & - & $\begin{array}{r}-1.061 \times 10^{-2} \\
\left(14.110^{*}\right) \\
\end{array}$ & $199.21^{* * *}$ & 0.823 & 97 \\
\hline \multirow{2}{*}{$\begin{array}{l}\text { 一般道路 } \\
\text { [第3·4種］ }\end{array}$} & 2車線 & 25.2 & $\begin{array}{l}-1.708 \\
\left(4.382^{*}\right)\end{array}$ & $\begin{array}{c}0.269 \\
\left(3.507^{*}\right)\end{array}$ & $\begin{array}{l}-3.191 \times 10^{-2} \\
(2.962 *)^{*}\end{array}$ & $\begin{array}{c}-5.623 \times 10^{-3} \\
\left(4.265^{3}\right)\end{array}$ & $29.16^{* * *}$ & 0.490 & 374 \\
\hline & 多車線 & 33.9 & $\begin{array}{l}-1.242 \\
\left(3.791^{*}\right)\end{array}$ & - & - & $\begin{array}{c}-9.647 \times 10^{-3}-3 \\
\left.(4.061)^{*}\right)\end{array}$ & $18.72^{* * *}$ & 0.451 & 150 \\
\hline
\end{tabular}

注）上段は偏回㷌係数、（）内は $\mathrm{t}$ 值を示す。*有意水篗 $0.1 \%$ で有意、**有意水準 $0.5 \%$ で有意、***有意水準 $1.0 \%$ 有意 
る。乙れはむしろ従来の日 $\mathrm{Q}-\mathrm{V}$ 式の勾配がきつす ぎたというべきであろう。また初速度と比較すると、 高速道路では提案した日 $\mathrm{Q}-\mathrm{V}$ 式の方が高目に出て おり、逆に一般道路では従来の日 $\mathrm{Q}-\mathrm{V}$ 式の方が低 目に出ている。乙れも実測データに表付けされた提 案日 $Q-V$ 式の方が妥当というべきであろう。

$7 \quad \sigma_{\eta}^{2}$ の推定

将来交通量を対象とした配分計算にあたっては、

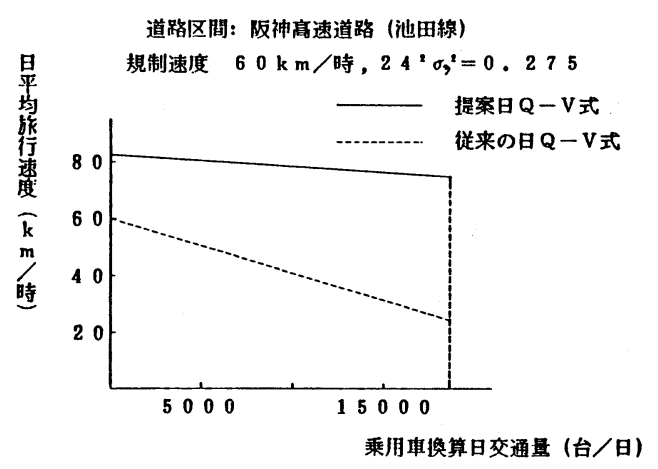

四-6 日Q-V式(都市高速道路 2 車線)

道路区間: 阪神高速道路 (塄状線) 4 車楾

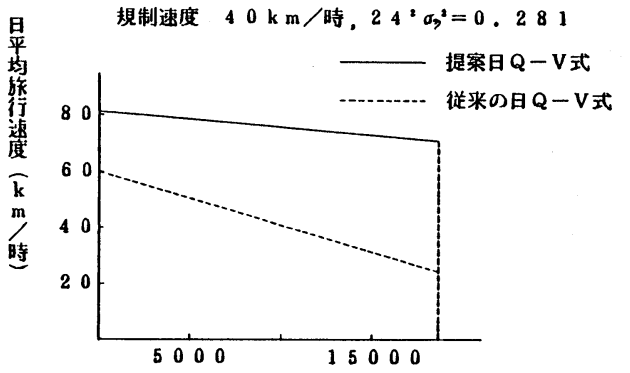

乘用車换算日交通量 (台/日)

図一，日Q-V式 (都市禹速道路 多本線)

道路区間: 国道 1 号線（名古屋市中川区下之一色町） 信号交差点然度: 2.973 筬所/ $\mathrm{km}$

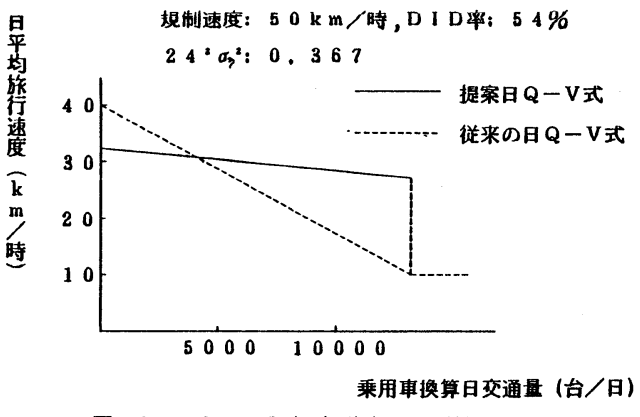

四-8 日Q-V式 (一般道路 2 車線)
道路区間: 主要地方道 (名古屋市中川区八脂通) 4 車線

信号交美点密度: 4.760 箅所 $/ \mathrm{km}$

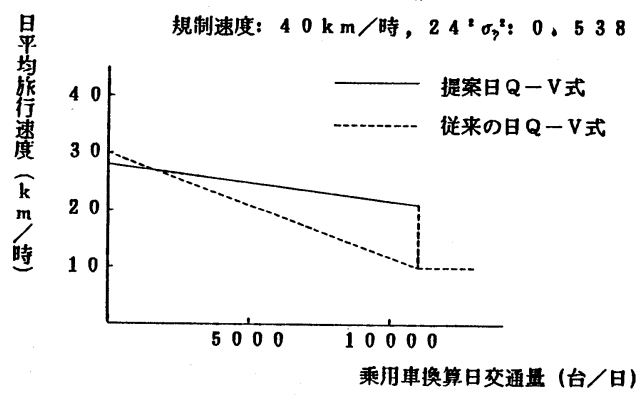

因-9 日Q - V 式 (一般道路 多車線)

各道路区間でとに将来の $\sigma_{2}^{2}$ の值と予測しておく必 要がある。ところで $\sigma_{\eta}^{2}$ の值は経年的にどのよう に変化するであ万弓か。図一10は名古屋市内 5 地 点での常時交通量観測データに基づいて計算された $\sigma_{\eta}^{2}$ の 経年変化を図示したものである。地点ごとに

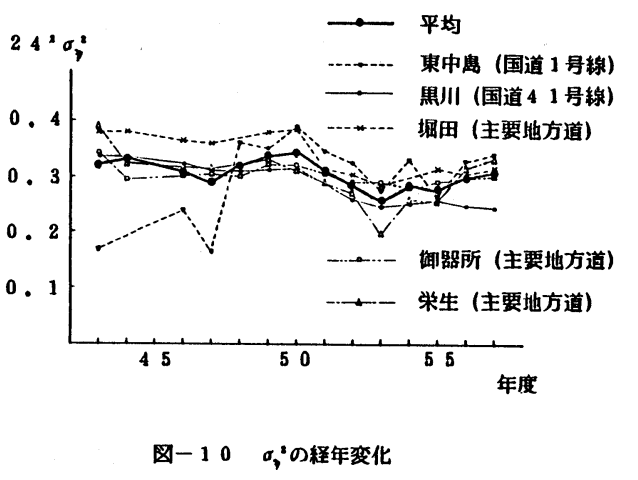

みるとそれそれ異なった変動をみせており、一般的 な傾向を読みとることができないが、5 地点の平均 でみると変動幅も小さくほぼ横ばい傾向を示してい る。たた $\sigma_{\eta}^{2}$ の経年変化についてはなお多くのデー 夕による分析が必要である。とてろで図一11は $\sigma_{\eta}^{2}$ と昼夜率との相関を示したものであるが、両者の間 には強い相関（相関係数一0.872）のあることがわ かる。すなわち時間変動の分散はほとんど昼夜率に よって特徵つけられると考えられる。表一 4 は昭和 55年度建設省交通量常時観测調查結果に基ついて、 道路の性格別にみた平均的な昼夜率を示したもので あるが ${ }^{18)} 、 乙 の$ 昼夜率の值を図一11中の式に代入し て $\sigma_{\eta}^{2}$ の值を求めたのが表一 4 の最右榴の檤である。 過去のデータから $\sigma_{\eta}^{2}$ の推定が可能な道路区間はょ いが、24時間の交通量調查の実施地点がまだ少ない 現状では、配分対象道路網のすべての道路区間の 
松井・藤田：

$\sigma_{2}^{2}$ を知ることは容易ではない。このような場合は、 道路区間をその性格によって区分し、表一 4 亿示す ような平均的な $\sigma_{2}^{2}$ の值を用いるととも考えられる。

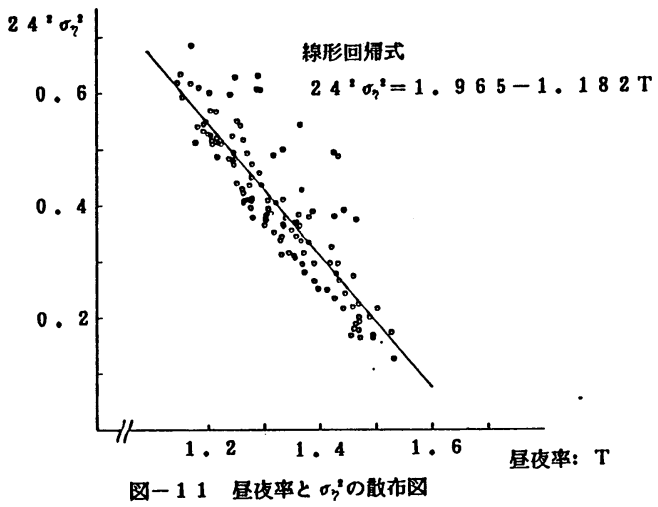

表-4 道路の性格と昼夜率, $\sigma_{7}^{2}$

\begin{tabular}{l|l|l}
\hline \multicolumn{1}{c|}{ 道路区分 } & 昼夜率 (平日) & $24^{2} \sigma_{7}^{2}$ \\
\hline 都市部 (幹線) & 1.45 & 0.25 \\
都市部 (その他) & 1.40 & 0.31 \\
地方部 (幹線一平地部) & 1.38 & 0.33 \\
地方部 (幹線一山地部) & 1.62 & 0.05 \\
観光道路 & 1.26 & 0.48 \\
\hline 全道路 & 1.35 & 0.28 \\
\hline
\end{tabular}

\section{8 結論と今後の検討課題}

本研究で得られた結論は以下のとおりである。

1) 実测データに基ついて作成した時間 $q ー U$ 式 と、交通量の時間変動特性を表わす分散とから、分 割配分法をはじめ一般的な交通量配分に適用できる 日Q-V式を理論的に導出することができた。

2) 時間 $q-v$ 式の作成のためのデータの分析結 果から、平均旅行速度に影響する要因が明らかにさ れた。

3) 時間変動特性を表わす分散の一般的な経年的 変動特性を明らかにすることはできなかったが、昼 夜率とは強い逆相関のあることがわかった。

4 ）道路交通センサスおよび都市高速道路の交通 量調査データを用いて実際に日 Q $-V$ 式を求め、従 来の日 $\mathrm{Q}-\mathrm{V}$ 式と比較することにより、その差異が 明らかにされた。

5 ）交通量配分にQ-V式を用いるととによって、 交通量の他旅行速度の計算結果も信頼に足る情報と して利用が可能となった。
一方今後の検討課題として次のような問題点をあげ ることができる

6) 時間 $q-v$ 式の作成江必要な旅行速度データ の信頼性に問題を残した。また、日Q-V式を求め るにあたっては、交通量の24時間調查地点数がまだ 少なく、したがって各道路区間の分散の与方方につ いて明解な方法を提案するまでにはいたらなかった。 7 ） 交通量配分計算の精度向上にあたっては、単 に $\mathrm{Q}-\mathrm{V}$ 式の与え方だけに止まらず、他の多くの課 題があり、提案日 $Q-V-V$ 式を用いただけでどの程度 精度向上に貢献するかは現段階では不明である。実 際の道路網への配分計算に適用し、従来のQ-V式 を用いた場合との比較検討が必要である。

最後に本研究にあたり、建設省中部地方建設局道 路計画第二課、名古屋市計画局街路計画課、阪神高 速道路公団計画部調査課から実測デー夕の提供を受 けた。乙てに感謝の意を表わすものである。

\section{参考文献}

1) Bureau of Public Road: Traffic Assignment Manual, 1964 2)Smock R.: An Iterative Assignment Approach to Capacity Restraint on Arterial Networks, H.R.B.347 1962 3) Irwin,Dodd and VanCube:Capacity Restraint in Assignment Programs, H.R.B,297,1961 4) Chicago Area Transportation Study Final Report, Vol .1, 1959 5) Pittsburgh Area Transportation Study, Vol.1, 1961 6) Davidson K.B,:A Flow-Travel Time Relationship for Use in Transportation Planning,Proc .Australian Road Researd Board,3,1984 7)北川，太田: 配分手法で用い ろQ-V式に関する考察, 交通工学, 19-3,1984 8)高速 道路調查会:旅行速度の設定方法に関する研究報告書 (II)， 1979 9)交通工学研究会編：交通工学ハンドブック，萿 法堂出版，1983 10)藤田萃弘: 分割配分法江用いるQ$\mathrm{V}$ 曲線の設定方法に関する研究, 名工大卒㖮 11)松井 寛:道路網にわける交通量配分理論について，交通工学，6 $-5,1971$ 12)井上博司: 道路網における等時間原則に上 万交通量配分比関する基硞的研究, 京大学位論文, 1975 13)大蔵, 北川, 森田: 一般道路における区間速度の特性, 高速道路と自動車, 24-7,1981 14)岩瀬, 浦野: 都市内 道路における旅行速度（時間）の推定手法, 交通工学,18$1,198315)$ 上高家，小山，中村:街路における旅行時留の 推定手法江関する研究,第 5 回交通工学研究発表会論文集, $198016)$ 过, 高橋, 川島, 山本: 街路誘導システムに おける旅行時間の予剆,オペレーションズリサーチ,1980 17)野津原,楠,杉山：京葉地区広域交通管制計画に扔ける 旅行時間予椡システム，高速道路と自動車 25-5,1982 18)建設省：昭和55年度交通量常時䘽测調查報告書, 1982 